\title{
Connexons and cell adhesion: a romantic phase
}

\author{
Nora Prochnow $\cdot$ Rolf Dermietzel
}

Accepted: 17 April 2008 / Published online: 15 May 2008

(C) Springer-Verlag 2008

\begin{abstract}
Recent evidence indicates, that gap junction forming proteins do not only contribute to intercellular communication (Kanno and Saffitz in Cardiovasc Pathol 10:169 177, 2001; Saez et al. in Physiol Rev 83:1359-1400, 2003), ion homeostasis and volume control (Goldberg et al. in J Biol Chem 277:36725-36730, 2002; Saez et al. in Physiol Rev 83:1359-1400, 2003). They also serve biological functions in a mechanical sense, supporting adherent connections between neighbouring cells of epithelial and non-epithelial tissues (Clair et al. in Exp Cell Res 314:1250-1265, 2008; Shaw et al. in Cell 128:547-560, 2007), where they stabilize migratory pathways in the developing central nervous system (Elias et al. in Nature 448:901-907, 2007; Malatesta et al. in Development 127:5253-5263, 2000; Noctor et al. in Nature 409:714-720, 2001; Rakic in Brain Res 33:471-476, 1971; J Comp Neurol 145:61-83 1972; Science 241:170$176,1988)$, or mediate polarized movements and directionality of neural crest cells during organogenesis (Kirby and Waldo in Circ Res 77:211-215, 1995; Xu et al. in Development 133:3629-3639, 2006). Since, most data describing adhesive properties of gap junctions delt with connexin 43 (Cx43) (Beardslee et al. in Circ Res 83:629-635, 1998), we will focus our brief review on this isoform.
\end{abstract}

Keywords Gap junction - Hemichannel - Cell adhesion . Heart $\cdot$ Developing brain

\footnotetext{
N. Prochnow $\cdot$ R. Dermietzel $(\square)$

Department of Neuroantomy and Molecular Brain Research, Ruhr University Bochum, Universitystreet 150,

44780 Bochum, Germany

e-mail: rolf.dermietzel@ rub.de

e-mail: rolf.dermietzel@ruhr-uni-bochum.de

N. Prochnow

e-mail: nora.prochnow@rub.de
}

\section{Introduction}

For those readers who are not familiar with the molecular composition of gap junctions, we will briefly recollect the substructure of this cell contact and refer to recent detailed reviews (Duffy et al. 2002; Gaietta et al. 2002; Goodenough and Paul 2003; Meier and Dermietzel 2006; Willecke et al. 2002).

Gap junctions are formed by hemichannels (connexons), which consist of an oligomer of six proteins (connexins). At present, at least 20 genes seem to be present in the human and rodent genome (Willecke et al. 2002), which may oligomerize in monomeric or heteromeric patterns to form a hemichannel. A complete gap junction channel is formed by two hemichannels in mirror symmetry (Fig. 1). Heterotypic configurations of different isoforms are allowed for some connexins while others occur exclusively in homotypic configuration. In the history of gap junctions, the junctional plaque has always been considered to occur in a "naked" form without cytoplasmic adjuncts like scaffolding proteins or cytoskeletal elements (Hirokawa and Heuser 1982). However, accruing evidence indicates that gap junctions are associated with a complex system of scaffolding and cytoskeletal proteins, which seem to assemble in cell specific patterns (Duffy et al. 2002 for recent review).

In the following, we will put main emphasis on heart and brain tissues for which most of the data on gap junctions and cell adhesion have been reviewed.

\section{Cardiomyocytes: directed trafficking of connexin 43 involves the cytoskeleton and adhesion plaques}

In the terminal intercalated discs between cardiomyocytes, $\mathrm{Cx} 43$ celebrates an example for integrating its hemichannel 


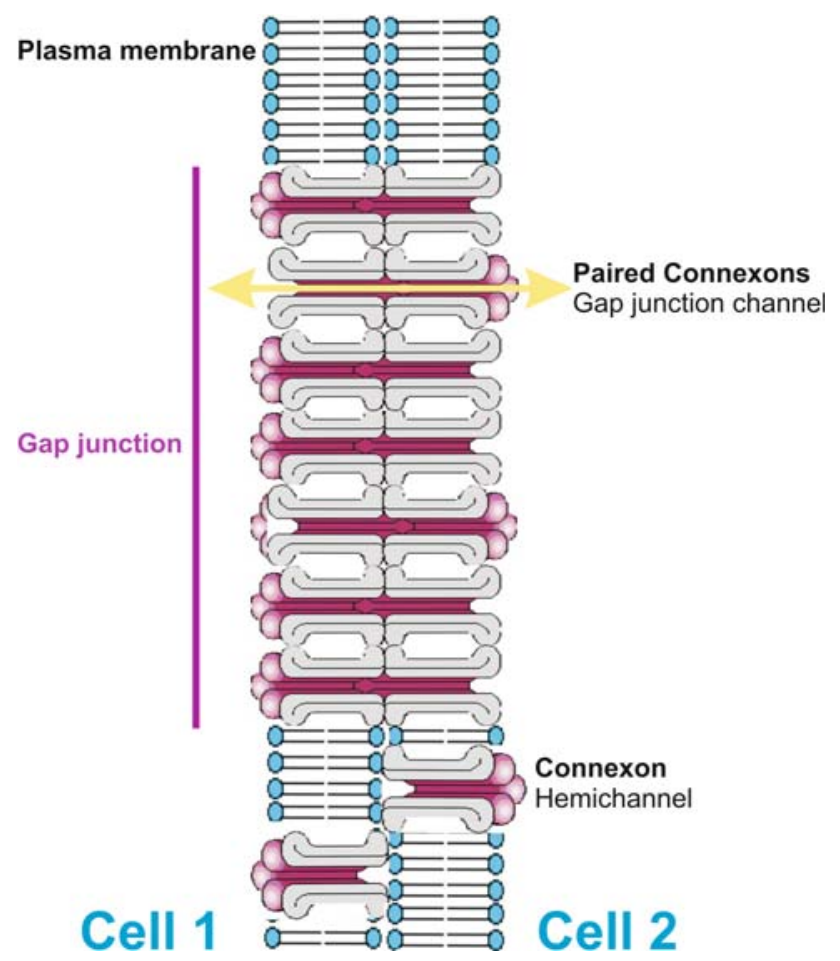

Fig. 1 General structure of a gap junction plaque. Gap junctions are formed by paired hemichannels (connexons) of two adjacent cells. A single connexon is made by a polymer of six connexins. Only apposed connexons allow intercellular transfer of ions (ionic coupling) and small metabolites (metabolic coupling). Unapposed connexons seem to perform per se functions

and cell coupling functions (Gros and Jongsma 1996; Shaw and Rudy 1997; van Veen et al. 2001). Asides the terminal intercalated discs, gap junctions are also localised in the lateral sarcolemma of the heart (Fig. 2), and thus described to form site-to-site and end-to-end connections (Yao et al.
2003). Cardiomyocytes also represent unopposed connexons with hemichannel function in the lateral sarcolemma (Saez et al. 2003; Schulz and Heusch 2006; Yao et al. 2003).

To ensure its' trafficking and functional integration into a gap junction plaque or in form of unpaired connexons (hemichannels) into the plasma membrane, Cx43 has to interact with other proteins. In the intercalated discs of coupled cardiomyocytes for instance, gap junction plaques are embedded into adherens junctions, which are primarily formed by cadherins (Matsuda et al. 2006; Niessen 2007; Zuppinger et al. 2000). Whilst the adherens junction supports the mechanical coupling (Gutstein et al. 2003; Niessen 2007), the gap junction ensures the propagation of action potentials along the cardiomyocytes (Gros and Jongsma 1996; Shaw and Rudy 1997).

Multiple models describe the pathway from connexon assembly to the initial gap junction formation and interaction with cadherins in the adherens junction. The most common examples are based on half-life time determined trafficking and junctional protein (cadherins) mediated activation of $\mathrm{Cx} 43$. The half-life time of $\mathrm{Cx} 43$ is restricted between 1 and $3 \mathrm{~h}$, and implicates a dynamic process of assembly, insertion and replacement of connexons, and pairing of connexons to form gap junctions (Beardslee et al. 1998; Hofer and Dermietzel 1998; Laird et al. 1991). Cx43 synthesis was shown to be located on membrane bound ribosomes, where connexin proteins are rapidly oligomerized into homo or heteromeric connexons (Evans et al. 1999; Martin and Evans 2004). Final packing into hemichannel loaded vesicles occurs in the trans-Golgi network as shown by Musil and Goudenough (1993) followed by directed transport along microtubules to multiple insertion sites in the membrane (Akhmanova and Hoogenraad 2005;
Fig. 2 a shows cultured cardiomyocytes immunolabelled with an anti-Cx43 antibody (red). Immunolabelling is prevalent in apposed cell membranes, but also in some unapposed domains. Nuclei are counterstained with Hoechst dye. b Immunolabelling of heart tissue with $\mathrm{Cx} 43$ antibody. Intercalated discs (red) are intensivley stained. Bar indicates $25 \mu \mathrm{m}$
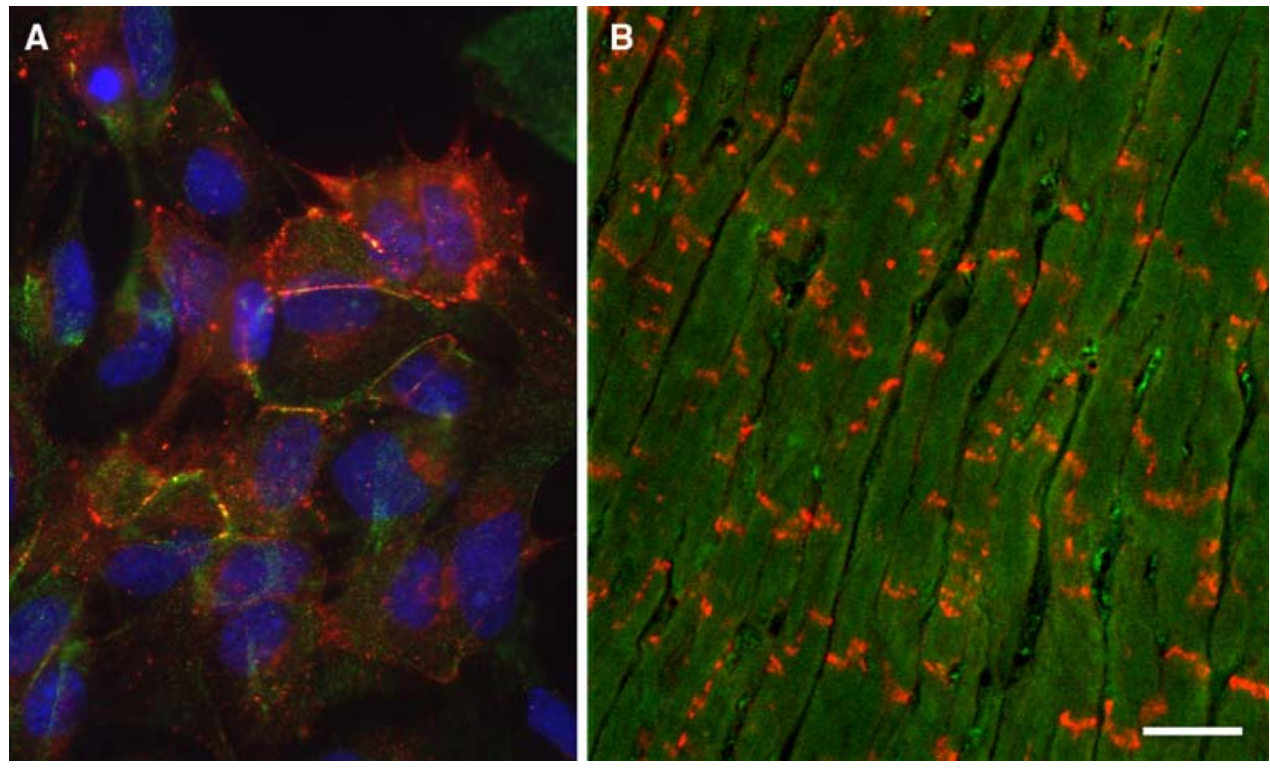
Jordan et al. 1999; Lauf et al. 2002; Mimori-Kiyosue et al. 2005; Shaw et al. 2007). Once arrived at the gap junction borders at the membrane, connexons are assumed to be inserted via flipping events into the membrane and to diffuse into the centre of the plaque, whilst elderly connexin proteins are shifted to the plaque periphery for subsequent disposal (Gaietta et al. 2002; Laird 2005; Segretain and Falk 2004).

The finding that mislocated $\mathrm{Cx} 43$ gap junction plaques in the ischemic myocardium are associated with similarly misplaced adherens junctions (Matsushita et al. 1999), underlines an interdependence between $\mathrm{Cx} 43$ and the adherens junction related cadherins (Angst et al. 1997; Li et al. 2005; Luo and Radice 2003; Matsushita et al. 1999). E-cadherin transfections into gap junction incompetent cells, allowed the transfectants to build out functional gap junctions (Matsushita et al. 1999). Furthermore, N-cadherin knockout mice (Luo and Radice 2003) and conditional knockdown of $\mathrm{N}$-cadherin in the heart caused mislocalisation and compromized expression of gap junctions. Conditional knockdown of $\mathrm{N}$-cadherin in the heart was additionally shown to lead to arrhythmogenic death (Li et al. 2005), which may involve aberrant regulation of gap junction function (for reviews see: Duffy et al. 2007)

Recently, Shaw et al. (2007) described microtubulemediated target-delivered transport of $\mathrm{Cx} 43$ via microtubule plus-end-tracking proteins (+TIPs) and interaction partners such as p150(GLUED) (Berrueta et al. 1999), a component of the dynein/dynactin complex, which in turn is potent to tether microtubules at the adherens junctions (Chausovsky et al. 2000; Ligon et al. 2001). Studies implicating fluorescence recovery after photobleaching (FRAP) on Cx43-YFP transfected HeLa cells that do not endogenously express $\mathrm{Cx} 43$, revealed a rapid $\mathrm{Cx} 43$ delivery to gap junction plaques. Deconvolution clarified that microtubules extend directly to the gap junction plaques at the cell's border and total internal reflection fluorescence (TIRF) microscopy and time lapse imaging revealed the appearance of a preferential and prolonged association of microtubule plus ends with the plaques. Most strikingly, Shaw et al. (2007) were able to show that gap junction plaque formation was disrupted by siRNA knockdown of the dimeric +TIP EB1. EB1 associates directly with the plus ends of microtubules and provides, in turn, dual binding sites for adherens junction related proteins like p150(GLUED) and $\beta$-catenin. Furthermore, in this setting gap junction plaques could also be disrupted via Nocodazol and Taxol treatment, peptides, which compromise the homophilic cadherin-cadherin interaction in adherens junctions. This setting according to the recent paper by Shaw et al. (2007) is sketched in the cartoon (Fig. 3). While Nocodazol interrupts formation of microtubules by depolimerization, Taxol lets microtubules remain stable, but interferes with their EB1 interaction partner (Nakata and Hirokawa 2003).

In this context, actin is discussed to act as an initial sensor of cell-cell interaction, driving the localisation of adherens junctions with assistance from Rho-GTPases (Noren et al. 2001, 2003).
Fig. 3 Model for microtubulus mediated delivery of vesiclebound connexons to adherens junctions (adapted from Shaw et al. 2007). Microtubules bind via their ${ }^{+}$end to EB1. EB1 in turn binds to P150 (GLUED), a component of the dynein/dynactin complex, which interacts with $\beta$-catenin through $\mathrm{P} 120$ catenin with the adherens junction. This interaction is understood to tether the microtubule to the junction and to serve as a gateway for connexon delivery

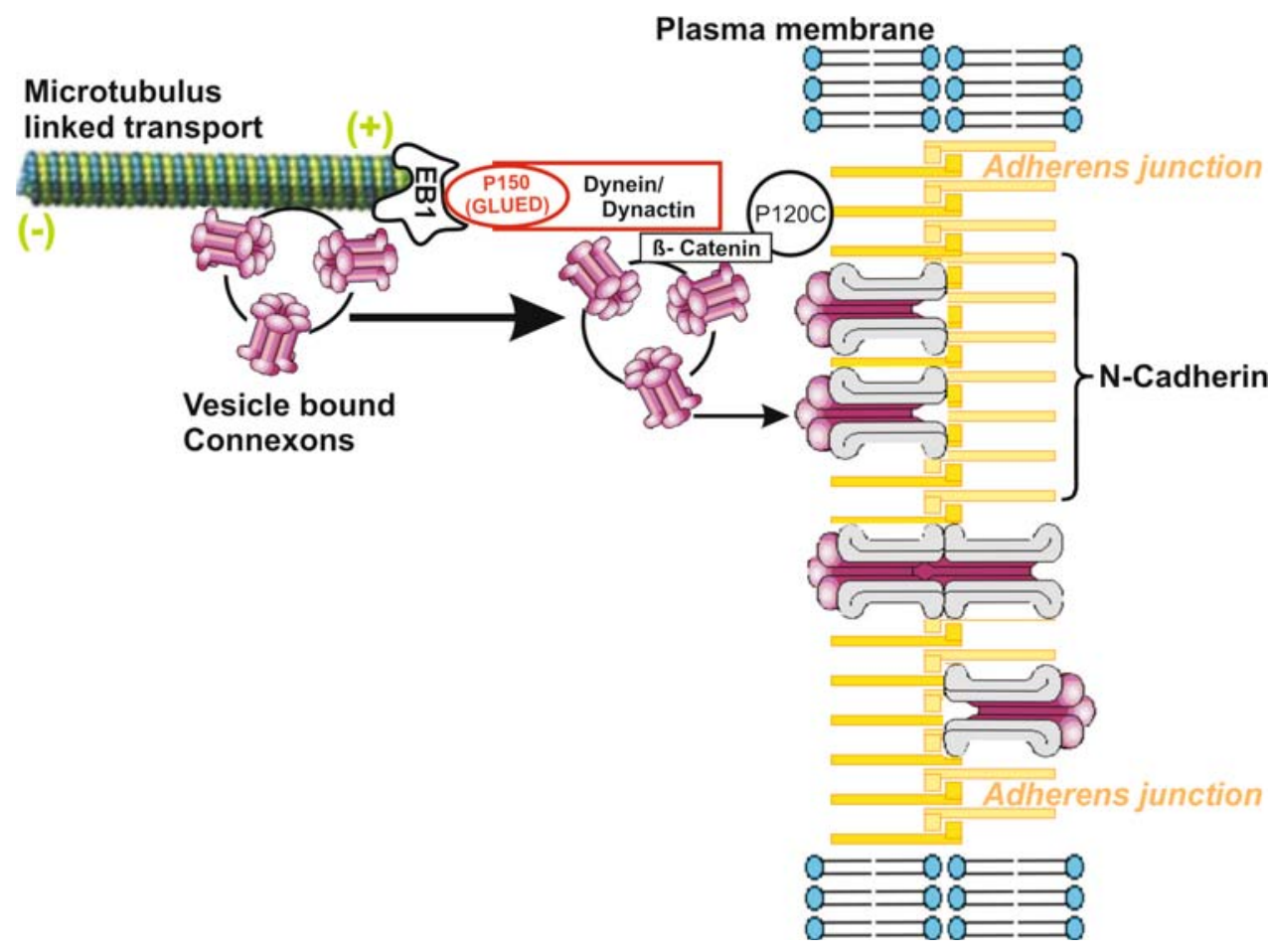




\section{Spread of Shigella flexneri requires connexin 43 hemichannels}

How close cytoskeletal (re-)organization and intracellular connexin distribution are related is demonstrated for polarized intestinal cells during Shigella flexneri invasion (Clair et al. 2008). For invading the colonic mucosa (Labrec et al. 1964), the gram negative enteric bacillus requires RhoGTPases, Src and Abl/Arg tyrosine kinases for actin polymerization and formation of cytoplasmic extensions of surrounding cells (Burton et al. 2003; Tran Van Nhieu et al. 2000). The invasion and dissemination of the bacteria causes intense inflammatory responses, and especially ATP-dependent paracrine signalling induced by $\mathrm{Cx}$ hemichannel opening (Tran Van Nhieu et al. 2000). E-cadherins were indispensable for the intercellular spreading of $S$. flexneri (Sansonetti et al. 1994). It is assumed that a cytoskeletal reorganization toward the formation zone of gap junctions is induced in this process to allow the spread of the bacteria (Clair et al. 2008; Tran Van Nhieu et al. 2000). On the epithelial level there is mounting evidence that connexin hemichannels regulate intercellular signalling (Stout et al. 2004), which might be of importance for incoming phagocytic cells during bacterial infection (Ferrari et al. 1997; Griffiths et al. 1995; John et al. 2001; Korcok et al. 2004).

\section{The developing brain and hemichannel adhesion}

The necessity of gap junction adhesion via regulation by its cytoskeleton interaction partners p120 catenin, integrin and actin has become well identified in the developing brain (Xu et al. 2001, 2006). Here, stem cells of the developing neocortex give rise to neurons (Malatesta et al. 2000; Noctor et al. 2001) and provide guidance of the developing neurons to the target zones of the cortical plate, where they are meant to become pyramidal cells of the adult cortex (Rakic 1971, 1972, 1988). Electron microscopy showed, that during the process of migration of neuronal precursors, gap junctions occur between radial fibres and migrating neurons and nestin - and nestin+ cells (Huang et al. 1998a). The most important gap junction protein isoforms are $\mathrm{Cx} 43$ and Cx26 in developing brain tissue (Dermietzel et al. 1989). Until now there was evidence that gap junctions between radial glia and migrating neurons served for chemical and electrical communication. Elias et al. (2007) recently found that $\mathrm{Cx} 26$ and $\mathrm{Cx} 43$ are expressed in $\beta$-III tubulin positive migrating neurons in the contacting regions close to vimentin positive radial glial fibres. Using a RNA knockdown of Cx43 and Cx26 by short hairpin RNA (shRNA) constructs in rat, the authors were able to demonstrate a reduced fractioning of neurons in the cortical plate. In addition, transplantation of $\mathrm{Cx} 26$ and $\mathrm{Cx} 43$ shRNA knocked down donor cells into E17 wildtype mice revealed an intact engrafting of the donor cells into the host brain, but no migration. Immunocytochemistry of the shRNA knocked down transplanted neurons in the recipient brains showed no compromised cell cycle exit and no alterations of differentiation. Furthermore, the expression of the adherens related proteins ZO-1, N-cadherin and $\beta$-integrin was not altered, indicating that gap junctions mediate glial-guided radial migration of developing neurons in the cortex. This migration was additionally demonstrated to rely on the adhesive and not on the channel properties of $\mathrm{Cx} 26$ or $\mathrm{Cx} 43$ (Elias et al. 2007). Dominant negative connexin mutants lacking channel properties were still able to form adhesive contacts. In reverse experiments, the authors demonstrated that channel, but no adhesion forming mutants, were unable to rescue the Cx43 shRNA induced migration defect. Finally, time lapse imaging of $\mathrm{Cx} 43 / \mathrm{Cx} 26$ shRNA expressing neurons affirmed their inability to stabilize their processes and to continue to extend along the radial glia.

\section{Neural crest cells and colonization}

Gap junction regulated polarized cell movements and directional migration are not restricted to developmental processes within the central nervous system (Elias et al. 2007; Schaar and McConnell 2005). Studies focusing on Cx43 expression of cardiac neural crest cells indicated a clear relationship between their migratory properties and $\mathrm{Cx} 43$ expression (Huang et al. 1998a, b; Li et al. 2002; Lo et al. 1999; Reaume et al. 1995; Sullivan and Lo 1995; Xu et al. 2001, 2006). Neural crest cells are ectomesenchymal cells emerging from epithelial mesenchymal cell transformation in the dorsal neural tube from where they disperse throughout the embryo to generate a variety of tissues (Kirby and Waldo 1995; Xu et al. 2006). Neural crest cells from different axial levels of the neural tube use multiple migratory pathways to reach their terminal destinations. Cardiac neural crest cells (CNCs) have been shown to migrate along a circumpharyngeal pathway to reach the aortic arches and the heart (Kirby et al. 1983; Lumsden et al. 1991). This deployment has been shown to be modulated by $\mathrm{Cx} 43$ and cytoskeletal interaction partners with the extracellular matrix (Xu et al. 2006). The finding, that dynamic di- and reassembly of focal contacts is essential for polarized cell movements and directional cell migration moved the heterodimeric receptor group of integrins into the centre of related studies. Integrins cluster to form focal domains within the cell membrane, linking the extracellular matrix to the actin cytoskeleton. Since, it could be shown that neural crest cells express multiple integrins (Delannet et al. 1994; Monier-Gavelle and Duband 1997) and perturbation studies provide evidence that integrins modulate the migratory behaviour of neural crest cells, (Strachan 
and Condic 2003, 2004, 2008) the question arose whether integrin signalling might be affected in $\mathrm{Cx} 43$ expressing versus Cx43 knock out cells (Xu et al. 2006).

In neural tube explants of the post-otic hindbrain folds from E8.5 mice, underlying either an $\mathrm{Cx} 43$ knockout or Cx43 overexpression, neural crest cells were generated that emerge from the same axial level as CNCs, which migrate to the heart. In contrast to overexpressing $\mathrm{CNCs}$, the $\mathrm{Cx} 43$ deficient $\mathrm{CNC}$ type was characterized by a severe loss of directionality and reduced adhesion whilst being cultured on a fibronectin matrix. Furthermore, an increase in the fibronectin matrix density leads to reductions in the migratory speed of $\mathrm{Cx} 43$ deficient $\mathrm{CNCs}$, as shown via time lapse videomicroscopy (Xu et al. 2001). In fact double-immunostaining against $\beta 1$-integrin and vinculin as markers for focal adhesion, was significantly reduced in $\mathrm{Cx} 43$ deficient $\mathrm{CNCs}$, indicating a reduction in the actin-cytoskeletal linkage for matrix adhesion. A modulatory influence of $\mathrm{Cx} 43$ on the actin cytoskeleton became evident in rhodamine-phalloidine stainings, where $\mathrm{Cx} 43$ knockout $\mathrm{CNCs}$ represented shorter stress fibre bundles (Xu et al. 2001). Additionally, these bundles exhibit no anchoring via vinculin to focal adhesions, as being observed for $\mathrm{Cx} 43$ overexpressing CNCs. Furthermore, adhesion and migration of $\mathrm{Cx} 43$ deficient $\mathrm{CNCs}$ on a fibronectin matrix could be inhibited by semaphorin application, which is described to act as a potent blocker of integrin activation (Brown et al. 2001). This approach also confirmed that $\mathrm{Cx} 43$ modulates the retraction of cellular processes. Immunoprecipitation, Western blot and immunocytochemistry pointed out that $\mathrm{Cx} 43$ in $\mathrm{CNCs}$ does not co-localise with $\beta 1$-integrin, but with vinculin and actin-filaments (Osborne et al. 2005; Pasterkamp and Kolodkin 2003; Serini et al. 2003; Xu et al. 2006). This finding is supported by the co-localisation of $\mathrm{Cx} 43$ with several actin binding proteins, such as ezrin, IQGAP, $\alpha$-actinin and drebrin (Butkevich et al. 2004). No correlation between gap junctional coupling properties and the density of fibronectin matrix was found for Cx43 knockouts and Cx43 overexpressing CNCs in dye coupling experiments, although an upregulation of gap junction communication with altered integrin-matrix interactions has previously been described for other cell types (Czyz et al. 2005; Lampe et al. 1998; Shanker et al. 2005).

In summary, asides their function as gap junction forming elements, unpaired connexons have been shown to modulate the cells' migratory and adhesive functions whilst being in permanent crosstalk with an elaborate complex of cytoskeletal interaction partners.

\section{Perspectives on pathology}

How important the connexin-cytoskeleton interaction is, becomes elucidated in case of pathology. For instance, cadherin-cadherin interactions might be critically affected during tumour formation. The interaction normally becomes active in cell sorting mechanisms during development (Wheelock and Johnson 2003). Since, Shaw et al. (2007) have shown that $\mathrm{Cx} 43$ can reach adherens junctions via microtubule directed delivery, it may be suggested that gap junctions are formed preferentially with cells, expressing the same type of cadherin (Wheelock and Johnson 2003). Additional studies provide evidence, that loss of Ecadherin or upregulation of $\mathrm{N}$-cadherin can increase tumour invasiveness and $\mathrm{Cx} 43$ downregulation in malignant cells (Mesnil 2002). It is thought that gap junction channels and their interactions with molecules such as p120 catenin, integrin and the actin cytoskeleton are important for neural crest cell migration (Xu et al. 2001, 2006), and that glioblastoma invasion of the brain parenchyma requires functional gap junctions between tumour cells and astrocytes (Lin et al. 2002). Furthermore, the migration of lung and skin cancer cells has also been associated with gap junction expression, although no clear mechanism has been proposed so far (Ito et al. 2000; Lois et al. 2002).

Developmental defects are also related to mutations of the Cx43 gene. As already indicated, Cx43 knockout mice reveal comprised conotruncal heart development, which is associated with a reduction in the number of cardiac neural crest cells targeted to the heart (Xu et al. 2006). Mutations in Cx43 which seem to influence cytoskeletal organization in a strong manner range from disease patterns like deafness, cataracts, germ cell developmental defects, ocludentodigital dysplasia to cardial outflow abnormalities (Polontchouk et al. 2002) and left ventricular remodelling (Kanno et al. 2003).

At its final extent, gap junction channels, in particular in form of hemichannels, constitute a new player in the complex interaction of cell adhesion and cytoskeletal activation, which underlies directed migration during development and in mature tissue. It is a romantic phase where anything may go, but time has to approve what will remain forever.

\section{References}

Akhmanova A, Hoogenraad CC (2005) Microtubule plus-end-tracking proteins: mechanisms and functions. Curr Opin Cell Biol 17:47-54

Angst BD, Khan LU, Severs NJ, Whitely K, Rothery S, Thompson RP, Magee AI, Gourdie RG (1997) Dissociated spatial patterning of gap junctions and cell adhesion junctions during postnatal differentiation of ventricular myocardium. Circ Res 80:88-94

Beardslee MA, Laing JG, Beyer EC, Saffitz JE (1998) Rapid turnover of connexin43 in the adult rat heart. Circ Res 83:629-635

Berrueta L, Tirnauer JS, Schuyler SC, Pellman D, Bierer BE (1999) The APC-associated protein EB1 associates with components of the dynactin complex and cytoplasmic dynein intermediate chain. Curr Biol 9:425-428

Brown CB, Feiner L, Lu MM, Li J, Ma X, Webber AL, Jia L, Raper JA, Epstein JA (2001) PlexinA2 and semaphorin signaling during cardiac neural crest development. Development 128:3071-3080 
Burton EA, Plattner R, Pendergast AM (2003) Abl tyrosine kinases are required for infection by Shigella flexneri. Embo J 22:5471-5479

Butkevich E, Hulsmann S, Wenzel D, Shirao T, Duden R, Majoul I (2004) Drebrin is a novel connexin-43 binding partner that links gap junctions to the submembrane cytoskeleton. Curr Biol 14:650-658

Chausovsky A, Bershadsky AD, Borisy GG (2000) Cadherin-mediated regulation of microtubule dynamics. Nat Cell Biol 2:797-804

Clair C, Combettes L, Pierre F, Sansonetti P, Tran Van Nhieu G (2008) Extracellular-loop peptide antibodies reveal a predominant hemichannel organization of connexins in polarized intestinal cells. Exp Cell Res 314:1250-1265

Czyz J, Guan K, Zeng Q, Wobus AM (2005) Loss of beta 1 integrin function results in upregulation of connexin expression in embryonic stem cell-derived cardiomyocytes. Int J Dev Biol 49:33-41

Delannet M, Martin F, Bossy B, Cheresh DA, Reichardt LF, Duband JL (1994) Specific roles of the alpha V beta 1, alpha V beta 3 and alpha $\mathrm{V}$ beta 5 integrins in avian neural crest cell adhesion and migration on vitronectin. Development 120:2687-2702

Dermietzel R, Traub O, Hwang TK, Beyer E, Bennett MV, Spray DC, Willecke K (1989) Differential expression of three gap junction proteins in developing and mature brain tissues. Proc Natl Acad Sci USA 86:10148-10152

Duffy HS, Delmar M, Spray DC (2002) Formation of the gap junction nexus: binding partners for connexins. J Physiol (Paris) 96:243-249

Duffy HS, Iacobas I, Hotchkiss K, Hirst-Jensen BJ, Bosco A, Dandachi N, Dermietzel R, Sorgen PL, Spray DC (2007) The gap junction protein connexin32 interacts with the Src homology 3/hook domain of discs large homolog 1. J Biol Chem 282:9789-9796

Elias LA, Wang DD, Kriegstein AR (2007) Gap junction adhesion is necessary for radial migration in the neocortex. Nature 448:901-907

Evans WH, Ahmad S, Diez J, George CH, Kendall JM, Martin PE (1999) Trafficking pathways leading to the formation of gap junctions. Novartis Found Symp 219:44-54 discussion 54-49

Ferrari D, Wesselborg S, Bauer MK, Schulze-Osthoff K (1997) Extracellular ATP activates transcription factor NF-kappaB through the P2Z purinoreceptor by selectively targeting NF-kappaB p65. J Cell Biol 139:1635-1643

Gaietta G, Deerinck TJ, Adams SR, Bouwer J, Tour O, Laird DW, Sosinsky GE, Tsien RY, Ellisman MH (2002) Multicolor and electron microscopic imaging of connexin trafficking. Science 296:503-507

Goldberg GS, Moreno AP, Lampe PD (2002) Gap junctions between cells expressing connexin 43 or 32 show inverse permselectivity to adenosine and ATP. J Biol Chem 277:36725-36730

Goodenough DA, Paul DL (2003) Beyond the gap: functions of unpaired connexon channels. Nat Rev Mol Cell Biol 4:285-294

Griffiths RJ, Stam EJ, Downs JT, Otterness IG (1995) ATP induces the release of IL-1 from LPS-primed cells in vivo. J Immunol 154:2821-2828

Gros DB, Jongsma HJ (1996) Connexins in mammalian heart function. Bioessays 18:719-730

Gutstein DE, Liu FY, Meyers MB, Choo A, Fishman GI (2003) The organization of adherens junctions and desmosomes at the cardiac intercalated disc is independent of gap junctions. J Cell Sci 116:875-885

Hirokawa N, Heuser J (1982) The inside and outside of gap-junction membranes visualized by deep etching. Cell 30:395-406

Hofer A, Dermietzel R (1998) Visualization and functional blocking of gap junction hemichannels (connexons) with antibodies against external loop domains in astrocytes. Glia 24:141-154

Huang GY, Cooper ES, Waldo K, Kirby ML, Gilula NB, Lo CW (1998a) Gap junction-mediated cell-cell communication modulates mouse neural crest migration. J Cell Biol 143:1725-1734

Huang GY, Wessels A, Smith BR, Linask KK, Ewart JL, Lo CW (1998b) Alteration in connexin 43 gap junction gene dosage impairs conotruncal heart development. Dev Biol 198:32-44
Ito A, Katoh F, Kataoka TR, Okada M, Tsubota N, Asada H, Yoshikawa K, Maeda S, Kitamura Y, Yamasaki H, Nojima H (2000) A role for heterologous gap junctions between melanoma and endothelial cells in metastasis. J Clin Invest 105:1189-1197

John GR, Simpson JE, Woodroofe MN, Lee SC, Brosnan CF (2001) Extracellular nucleotides differentially regulate interleukin-1beta signaling in primary human astrocytes: implications for inflammatory gene expression. J Neurosci 21:4134-4142

Jordan K, Solan JL, Dominguez M, Sia M, Hand A, Lampe PD, Laird DW (1999) Trafficking, assembly, and function of a connexin43green fluorescent protein chimera in live mammalian cells. Mol Biol Cell 10:2033-2050

Kanno S, Kovacs A, Yamada KA, Saffitz JE (2003) Connexin43 as a determinant of myocardial infarct size following coronary occlusion in mice. J Am Coll Cardiol 41:681-686

Kanno S, Saffitz JE (2001) The role of myocardial gap junctions in electrical conduction and arrhythmogenesis. Cardiovasc Pathol 10:169-177

Kirby ML, Gale TF, Stewart DE (1983) Neural crest cells contribute to normal aorticopulmonary septation. Science 220:1059-1061

Kirby ML, Waldo KL (1995) Neural crest and cardiovascular patterning. Circ Res 77:211-215

Korcok J, Raimundo LN, Ke HZ, Sims SM, Dixon SJ (2004) Extracellular nucleotides act through $\mathrm{P} 2 \mathrm{X} 7$ receptors to activate NF-kappaB in osteoclasts. J Bone Miner Res 19:642-651

Labrec EH, Schneider H, Magnani TJ, Formal SB (1964) Epithelial Cell Penetration as an Essential Step in the Pathogenesis of Bacillary Dysentery. J Bacteriol 88:1503-1518

Laird DW (2005) Connexin phosphorylation as a regulatory event linked to gap junction internalization and degradation. Biochim Biophys Acta 1711:172-182

Laird DW, Puranam KL, Revel JP (1991) Turnover and phosphorylation dynamics of connexin43 gap junction protein in cultured cardiac myocytes. Biochem J 273(Pt 1):67-72

Lampe PD, Nguyen BP, Gil S, Usui M, Olerud J, Takada Y, Carter WG (1998) Cellular interaction of integrin alpha3beta1 with laminin 5 promotes gap junctional communication. J Cell Biol 143:1735-1747

Lauf U, Giepmans BN, Lopez P, Braconnot S, Chen SC, Falk MM (2002) Dynamic trafficking and delivery of connexons to the plasma membrane and accretion to gap junctions in living cells. Proc Natl Acad Sci USA 99:10446-10451

Li J, Patel VV, Kostetskii I, Xiong Y, Chu AF, Jacobson JT, Yu C, Morley GE, Molkentin JD, Radice GL (2005) Cardiac-specific loss of N-cadherin leads to alteration in connexins with conduction slowing and arrhythmogenesis. Circ Res 97:474-481

Li WE, Waldo K, Linask KL, Chen T, Wessels A, Parmacek MS, Kirby ML, Lo CW (2002) An essential role for connexin43 gap junctions in mouse coronary artery development. Development 129:2031-2042

Ligon LA, Karki S, Tokito M, Holzbaur EL (2001) Dynein binds to beta-catenin and may tether microtubules at adherens junctions. Nat Cell Biol 3:913-917

Lin JH, Takano T, Cotrina ML, Arcuino G, Kang J, Liu S, Gao Q, Jiang L, Li F, Lichtenberg-Frate H, Haubrich S, Willecke K, Goldman SA, Nedergaard M (2002) Connexin 43 enhances the adhesivity and mediates the invasion of malignant glioma cells. J Neurosci 22:4302-4311

Lo CW, Waldo KL, Kirby ML (1999) Gap junction communication and the modulation of cardiac neural crest cells. Trends Cardiovasc Med 9:63-69

Lois C, Hong EJ, Pease S, Brown EJ, Baltimore D (2002) Germline transmission and tissue-specific expression of transgenes delivered by lentiviral vectors. Science 295:868-872

Lumsden A, Sprawson N, Graham A (1991) Segmental origin and migration of neural crest cells in the hindbrain region of the chick embryo. Development 113:1281-1291 
Luo Y, Radice GL (2003) Cadherin-mediated adhesion is essential for myofibril continuity across the plasma membrane but not for assembly of the contractile apparatus. J Cell Sci 116:1471-1479

Malatesta P, Hartfuss E, Gotz M (2000) Isolation of radial glial cells by fluorescent-activated cell sorting reveals a neuronal lineage. Development 127:5253-5263

Martin PE, Evans WH (2004) Incorporation of connexins into plasma membranes and gap junctions. Cardiovasc Res 62:378-387

Matsuda T, Fujio Y, Nariai T, Ito T, Yamane M, Takatani T, Takahashi K, Azuma J (2006) N-cadherin signals through Racl determine the localization of connexin 43 in cardiac myocytes. J Mol Cell Cardiol 40:495-502

Matsushita T, Oyamada M, Fujimoto K, Yasuda Y, Masuda S, Wada Y, Oka T, Takamatsu T (1999) Remodeling of cell-cell and cellextracellular matrix interactions at the border zone of rat myocardial infarcts. Circ Res 85:1046-1055

Meier C, Dermietzel R (2006) Electrical synapses-gap junctions in the brain. Results Probl Cell Differ 43:99-128

Mesnil M (2002) Connexins and cancer. Biol Cell 94:493-500

Mimori-Kiyosue Y, Grigoriev I, Lansbergen G, Sasaki H, Matsui C, Severin F, Galjart N, Grosveld F, Vorobjev I, Tsukita S, Akhmanova A (2005) CLASP1 and CLASP2 bind to EB1 and regulate microtubule plus-end dynamics at the cell cortex. J Cell Biol 168:141-153

Monier-Gavelle F, Duband JL (1997) Cross talk between adhesion molecules: control of $\mathrm{N}$-cadherin activity by intracellular signals elicited by beta 1 and beta 3 integrins in migrating neural crest cells. J Cell Biol 137:1663-1681

Musil LS, Goodenough DA (1993) Multisubunit assembly of an intergral plasma membrane channel protein, gap junction connexin 43, occurs after exit from the ER. Cell 74:1065-1077

Nakata T, Hirokawa N (2003) Microtubules provide directional cues for polarized axonal transport through interaction with kinesin motor head. J Cell Biol 162:1045-1055

Niessen CM (2007) Tight junctions/adherens junctions: basic structure and function. J Invest Dermatol 127:2525-2532

Noctor SC, Flint AC, Weissman TA, Dammerman RS, Kriegstein AR (2001) Neurons derived from radial glial cells establish radial units in neocortex. Nature 409:714-720

Noren NK, Arthur WT, Burridge K (2003) Cadherin engagement inhibits RhoA via p190RhoGAP. J Biol Chem 278:13615-13618

Noren NK, Niessen CM, Gumbiner BM, Burridge K (2001) Cadherin engagement regulates Rho family GTPases. J Biol Chem 276:33305-33308

Osborne NJ, Begbie J, Chilton JK, Schmidt H, Eickholt BJ (2005) Semaphorin/neuropilin signaling influences the positioning of migratory neural crest cells within the hindbrain region of the chick. Dev Dyn 232:939-949

Pasterkamp RJ, Kolodkin AL (2003) Semaphorin junction: making tracks toward neural connectivity. Curr Opin Neurobiol 13:79-89

Polontchouk LO, Valiunas V, Haefliger JA, Eppenberger HM, Weingart R (2002) Expression and regulation of connexins in cultured ventricular myocytes isolated from adult rat hearts. Pflugers Arch 443:676-689

Rakic P (1971) Guidance of neurons migrating to the fetal monkey neocortex. Brain Res 33:471-476

Rakic P (1972) Mode of cell migration to the superficial layers of fetal monkey neocortex. J Comp Neurol 145:61-83

Rakic P (1988) Specification of cerebral cortical areas. Science 241:170-176

Reaume AG, de Sousa PA, Kulkarni S, Langille BL, Zhu D, Davies TC, Juneja SC, Kidder GM, Rossant J (1995) Cardiac malformation in neonatal mice lacking connexin43. Science 267:1831-1834

Saez JC, Berthoud VM, Branes MC, Martinez AD, Beyer EC (2003) Plasma membrane channels formed by connexins: their regulation and functions. Physiol Rev 83:1359-1400
Sansonetti PJ, Mounier J, Prevost MC, Mege RM (1994) Cadherin expression is required for the spread of Shigella flexneri between epithelial cells. Cell 76:829-839

Schaar BT, McConnell SK (2005) Cytoskeletal coordination during neuronal migration. Proc Natl Acad Sci USA 102:13652-13657

Schulz R, Heusch G (2006) Connexin 43 and ischemic preconditioning. Adv Cardiol 42:213-227

Segretain D, Falk MM (2004) Regulation of connexin biosynthesis, assembly, gap junction formation, and removal. Biochim Biophys Acta 1662:3-21

Serini G, Valdembri D, Zanivan S, Morterra G, Burkhardt C, Caccavari F, Zammataro L, Primo L, Tamagnone L, Logan M, TessierLavigne M, Taniguchi M, Puschel AW, Bussolino F (2003) Class 3 semaphorins control vascular morphogenesis by inhibiting integrin function. Nature 424:391-397

Shanker AJ, Yamada K, Green KG, Yamada KA, Saffitz JE (2005) Matrix-protein-specific regulation of $\mathrm{Cx} 43$ expression in cardiac myocytes subjected to mechanical load. Circ Res 96:558-566

Shaw RM, Fay AJ, Puthenveedu MA, von Zastrow M, Jan YN, Jan LY (2007) Microtubule plus-end-tracking proteins target gap junctions directly from the cell interior to adherens junctions. Cell 128:547-560

Shaw RM, Rudy Y (1997) Ionic mechanisms of propagation in cardiac tissue. Roles of the sodium and L-type calcium currents during reduced excitability and decreased gap junction coupling. Circ Res $81: 727-741$

Stout C, Goodenough DA, Paul DL (2004) Connexins: functions without junctions. Curr Opin Cell Biol 16:507-512

Strachan LR, Condic ML (2003) Neural crest motility and integrin regulation are distinct in cranial and trunk populations. Dev Biol 259:288-302

Strachan LR, Condic ML (2004) Cranial neural crest recycle surface integrins in a substratum-dependent manner to promote rapid motility. J Cell Biol 167:545-554

Strachan LR, Condic ML (2008) Neural crest motility on fibronectin is regulated by integrin activation. Exp Cell Res 314:441-452

Sullivan R, Lo CW (1995) Expression of a connexin 43/beta-galactosidase fusion protein inhibits gap junctional communication in NIH3T3 cells. J Cell Biol 130:419-429

Tran Van Nhieu G, Bourdet-Sicard R, Dumenil G, Blocker A, Sansonetti PJ (2000) Bacterial signals and cell responses during Shigella entry into epithelial cells. Cell Microbiol 2:187-193

van Veen AA, van Rijen HV, Opthof T (2001) Cardiac gap junction channels: modulation of expression and channel properties. Cardiovasc Res 51:217-229

Wheelock MJ, Johnson KR (2003) Cadherins as modulators of cellular phenotype. Annu Rev Cell Dev Biol 19:207-235

Willecke K, Eiberger J, Degen J, Eckardt D, Romualdi A, Guldenagel M, Deutsch U, Sohl G (2002) Structural and functional diversity of connexin genes in the mouse and human genome. Biol Chem 383:725-737

Xu X, Francis R, Wei CJ, Linask KL, Lo CW (2006) Connexin 43 mediated modulation of polarized cell movement and the directional migration of cardiac neural crest cells. Development 133:3629-3639

Xu X, Li WE, Huang GY, Meyer R, Chen T, Luo Y, Thomas MP, Radice GL, Lo CW (2001) Modulation of mouse neural crest cell motility by $\mathrm{N}$-cadherin and connexin 43 gap junctions. J Cell Biol 154:217-230

Yao JA, Gutstein DE, Liu F, Fishman GI, Wit AL (2003) Cell coupling between ventricular myocyte pairs from connexin43-deficient murine hearts. Circ Res 93:736-743

Zuppinger C, Eppenberger-Eberhardt M, Eppenberger HM (2000) $\mathrm{N}$-Cadherin: structure, function and importance in the formation of new intercalated disc-like cell contacts in cardiomyocytes. Heart Fail Rev 5:251-257 